\title{
Lasten kokopäivähoidon tarve Espoossa ${ }^{1}$
}

\author{
VIRPI SEPPÄNEN
}

\section{Johdanto}

Lasten päivähoidon järjestämisestä on kaupunkimaisessa elinympäristössä muodostunut varsin monitahoinen sosiaalinen ongelma. Ansiotyöäitien lukumäärän jatkuvasti kasvaessa työssäkäyntimahdollisuuksien sekä työpaikkojen että niissä tarvittavan koulutuksen lisääntymisen vuoksi on päivähoitokysymys käynyt yhä ajankohtaisemmaksi ja siihen on kiinnitetty kasvavaa huomiota myös julkisuudessa. Suurelta osalta on lasten päivähoitotoiminnan toistaiseksi todettava olevan valvomatonta ja perustuvan yksityiseen perhepäivähoitoon, sillä laitospäivähoito on maassamme melko harvinaista. Näin on varsinkin alle 3-vuotiaiden lasten kohdalla, joille ei tämän hoitomuodon, pääasiassa sen laitosmaisuuden takia, yleensä katsota soveltuvan.

Lasten päivähoito-ongelmaa tarkasteltaessa ovat hyvin keskeisenä kysymyksenä yleensä myös kustannukset. Yksityinen ansioäiti voi saada lastensa päivähoidon järjestymään joko lähes ilmaiseksi isoäidin tai muun sukulaisen turvin tai joutua maksamaan siitä kalliisti vieraalle perhepäivähoitokodille. Laitoshoidon kustannukset ovat yksityiselle perheelle yleensä huokeat, mutta saattavat laitoksen tasosta ja paikkojen lukumäärästä riippuen olla varsin kalliit laitoksen ylläpitäjälle. Tämä johtuu siitä, että päivähoitolaitoksissa (etenkin kunnallisissa) peritään lasten vanhemmilta vain ns. ruokamaksu, joka yleensä on varsin pieni todellisiin kustannuksiin verrattuna.

Viime aikoina on julkisessa keskustelussa tullut esiin eräänä lasten päivähoitokysymyksen osaratkaisumahdollisuutena myös ns. äidinpalkkaajatus, jolla on tarkoitettu taloudellisen tuen myöntämistä kotona oleville, alle 3-vuotiaita lapsiaan hoitaville äideille. Asiaan lienee yleensä suhtauduttu myönteisesti, vaikkakin sitä tutkinut perhekustannusten tasauskomitea (1966) on todennut, ettei äidinpalkkasuunnitelman valtakunnallinen toteuttaminen ole lähivuosina mahdollista. Viimemainitusta syystä ei komitea myöskään voinut laatia yksityiskohtaista ehdotusta äidinpalkkajärjestelmän toteuttamisesta.

Tämä tutkimus on lähtenyt liikkeelle siitä, että Espoon kauppalassa on tehty ehdotus "äidinpalkka»-järjestelmän kokeilemisesta kotona oleville, alle kouluikäisten lasten äideille myönnettävänä, tapauskohtaisena, harkin-

1 Lyhennelmä Virpi Seppäsen laatimasta selvityksestä: Tutkimus alle kouluikäisten lasten päivähoidosta Espoon kauppalassa. (Moniste). Espoo 1967. 
taan perustuvana avustusmuotona. Tutkimuksen yhteydessä on katsottu tarkoituksenmukaiseksi selvittää paitsi lasten kokopäivähoidon tarpeeseen vaikuttavia tekijöitä myös eräitä muita lasten päivähoitokysymykseen olennaisesti liittyviä seikkoja.

\section{Tutkimustehtävä}

Tutkimusta suunniteltaessa tuntui varsin luonnolliselta lähteä liikkeelle siitä, millaisena kokopäivähoidon tarve oli nähty tähän mennessä Espoossa jo toiminnassa olevilla kauppalan lastentarhojen kokopäiväosastoilla. Tätä tarkoitusta varten koottiin tietoja kokopäivähoitoon ottamisen syistä ja perheiden taloudellisesta asemasta. Yleispiirteenä voitiin todeta, että lasten kunnallisen kokopäivähoidon luonne on ollut sosiaalinen, toisin sanoen se on kohdistunut vähävaraisten ja suurelta osalta ainoiden huoltajien lapsiin. Hoidontarve on tutkittu kussakin tapauksessa erikseen ja kokopäivähoitoon pääsyn yleisenä edellytyksenä on ollut, että lapsen äidin työssäkäyntiä on syystä tai toisesta pidetty välttämättömänä perheen toimeentulon kannalta. Niinpä kokonaista $62 \%$ perheistä, joista lapsia oli kokopäiväosastoilla, oli yhden huoltajan perheitä. Toinen yleisimmistä hoitoonpääsyn perusteista oli isän asosiaalisuus (23\%) ja siitä johtuva perheen toimeentulon vaikeutuminen sekä äidin työssäkäynnin välttämättömyys. Lopuissa tapauksissa $(15 \%)$ aiheutuivat perheen taloudelliset vaikeudet isän työkyvyttömyydestä tai muusta syystä.

Perheiden taloudellista asemaa kuvaavat niiden keskimääräiset nettoansiot, joiksi saatiin $620 \mathrm{mk}$ kuukaudessa. Olennaisena seikkana liittyi kuvaan vielä se, että näissä perheissä olivat naisten nettotulot keskimäärin suuremmat $(416 \mathrm{mk} / \mathrm{kk})$ kuin miesten tulot, jotka olivat keskimäärin vain $263 \mathrm{mk} / \mathrm{kk}$. Kokopäivähoitoon pääsyn tiukasta valvonnasta on osoituksena näillä osastoilla olevien lasten suhteellisen pieni lukumäärä. Vuoden 1966 alussa oli näillä osastoilla 61 lasta eli n. 8,7 \% kaikkien pienituloisten perheiden kokopäivätyössä käyvien äitien 3-7-vuotisista alle kouluikäisistä lapsista, vastaavan luvun ollessa äiti ja lapsi -perheiden kohdalla n. $16 \%$.

Tutkimuksen tarkoituksena on mahdollisimman monipuolisesti selvitellä edellä kuvatuin perustein määritellyn tapaiseen kokopäivähoidon tarpeeseen vaikuttavia tekijöitä. Kokopäivähoidon tarve jakaantuu lasten iän mukaan kahteen osaan, nimittäin alle 3-vuotiaiden ja 3-7-vuotiaiden lasten kokopäivähoidon tarpeeseen.

Tutkimuksen suorittamiseksi oli tarpeen saada riittävä joukko perheitä, joiden kannalta e.m. kysymysten selvittäminen olisi tarkoituksenmukaista. Ensimmäiseksi edellytykseksi tutkimusryhmään valittaville asetettiin luonnollisesti se, että heillä oli a lle kouluikäisiä lapsia.

Toiseksi katsottiin tarpeelliseksi rajoittaa tutkimus koskemaan vain ns. pienituloisia perheitä. Tarkoitukseen sopivana ja riittävän 
Taulukko 1. Tutkimukseen hyväksyttyjen erisuuruisten perheiden tulorajat

Table 1. Distribution of the sample according to total family income

\begin{tabular}{ccc}
\hline $\begin{array}{c}\text { Lasten lukumäärä } \\
\text { Number of children }\end{array}$ & $\begin{array}{c}\text { Kokonaistulot vuodessa } \\
\text { Total annual income }\end{array}$ & $\begin{array}{c}\text { Kokonaistulot } \\
\text { kuukaudessa } \mathrm{n} . \\
\text { Total monthly income }\end{array}$ \\
\hline 1 & 9.500 & 790 \\
2 & 10.000 & 830 \\
3 & 11.000 & 920 \\
4 & 12.500 & 1.040 \\
5 & 14.500 & 1.208 \\
7 & 16.500 & 1.370 \\
\end{tabular}

edustavana pidettiin väestölaskentaa varten syksyllä 1965 poimittua otantaa, jossa lisäksi koottiin tulotietoja. Tutkimusryhmän valinta tapahtui siten, että otoksesta poimittiin kaikki sellaiset perheet, joilla oli vähintäin yksi alle kouluikäinen (v. 1959 tai sitä myöhemmin syntynyt) lapsi, ja joiden päämiehen kokonaistulot eivät vuonna 1965 ylittäneet tiettyjä rajoja.

Pienituloiset perheet on tässä tutkimuksessa määritelty siten, että lähtökohdaksi on otettu aikaisemmin mainittujen perheiden keskimääräiset tulot eli yksilapsisissa perheissä päämiesten nettotulot saivat olla enintään $650 \mathrm{mk}$ kuukaudessa (bruttotulot keskim. $790 \mathrm{mk} / \mathrm{kk}$ ). Porrastusta on supistettu perhelisätulorajoihin verrattuna useampilapsisten perheiden kohdalla, jolloin tulorajat muodostuivat taulukon 1 mukaiseksi.

Taulukossa 1 esitettyjä tulorajoja noudattaen väestölaskentaotoksesta poimittiin 547 sellaista perhettä, joilla oli alle 7-vuotiaita lapsia. Tämä oli lähes kolmasosa otokseen sisältyneiden lapsiperheiden kokonaismäärästä, otoksen edustaessa noin viidettä osaa Espoon väestöstä. Näin muodostetulle tutkimusryhmälle suunniteltiin haastattelulomakkeet ja haastattelut suoritettiin sosiaalitarkkaajien, heidän sijaistensa ja lastentarhanopettajien toimesta touko-kesäkuussa 1966. Haastatteluja tehtiin kaikkiaan 452 ja palautusprosentiksi saatiin $83 \%$, mitä voitanee pitää normaalina tämän kaltaisissa tutkimuksissa. Poisjääminen johtui pääasiassa siitä, että osa haastateltavista oli muuttanut pois Espoosta väestölaskennan ja haastattelun välisenä puolen vuoden aikana.

\section{Tutkimustulokset}

Lasten päivähoito

Ikänsä puolesta lapset on jaettu kahteen ryhmään, alle 3-vuotiaisiin ja 3-7-vuotiaisiin. Kolmen päähoitomuodon mukaan jakaantuivat kodin ulkopuolella ansiotyössäkäyvien äitien lapset taulukon 2 mukaisesti. 
T a u l ukko 2. Lasten hoitomuodot tutkimusperheissä

Table 2. Types of arrangements for day care of children

\begin{tabular}{|c|c|c|}
\hline & $\begin{array}{l}\text { Alle } 3 \text {-vuotiaat } \\
\text { Under } 3 \text { years of age }\end{array}$ & $\begin{array}{l}3-7 \text {-vuotiaat } \\
\text { Between the ages } \\
\text { of } 3-7\end{array}$ \\
\hline & $\%$ & $\%$ \\
\hline $\begin{array}{l}\text { Kotihoidossa } \\
\text { Home care }\end{array}$ & 43 & 40 \\
\hline $\begin{array}{l}\text { Perhepäivähoidossa } \\
\text { Private care outside the home }\end{array}$ & 53 & 32 \\
\hline $\begin{array}{l}\text { Private care outside the home } \\
\text { Laitospäivähoidossa }\end{array}$ & - & 20 \\
\hline Institutional day care & & \\
\hline \multirow{2}{*}{$\begin{array}{l}\text { Muussa hoidossa ..... } \\
\text { Other care }\end{array}$} & 4 & 8 \\
\hline & 100 & 100 \\
\hline
\end{tabular}

K otihoid o n yleisimpänä hoitomuotona oli, että lapset olivat sukulaisen hoidossa kotona, jolloin hoitajana oli yleensä isoäiti. Tämä hoitotapa oli jonkin verran yleisempi alle kolmevuotiailla kuin sitä vanhemmilla lapsilla ja edelleen hieman yleisempi kokopäivätyössä käyvien äitien lapsilla kuin kaikkien ansiotyössäkäyvien äitien lapsilla. Toiseksi yleisin kotihoitomuoto, perheenjäsenen hoidossa kotona, oli sensijaan, päinvastoin kuin viimeksimainittu, yleisempi 3-7-vuotiailla ja kaikkien ansiotyössäkäyvien äitien lapsilla kuin alle kolmevuotiailla ja kokopäivätyössä käyvien äitien lapsilla. Viimemainittu seikka tuntuukin varsin luonnolliselta, sillä harvoin on kotona sellaisia perheenjäseniä (paitsi äiti), jotka voisivat tai pystyisivät hoitamaan koko päivän pientä, alle kolmevuotiasta lasta. Kotihoidon kolmas vaihtoehto, lastenhoitaja tai kotiapulainen, oli tutkimusperheissä ilmeisesti taloudellisista syistä varsin harvinainen hoitotapa, sillä alle kymmenen prosenttia ansioäitien lapsista oli tässä asemassa. Verrattaessa kokopäivätyössä käyvien äitien lapsia ja kaikkien ansiotyössäkäyvien äitien lapsia keskenään oli tämä hoitomuoto ensiksi mainituilla suhteellisesti hieman yleisempi kuin viimemainituilla.

Perhepäivähoito yksityiskodissa, joko sukulaisen luona tai vieraassa perheessä, oli yleisin hoitomuoto alle 3-vuotiaiden ikäryhmässä ja myös 3-7-vuotiaista oli $\mathrm{n}$. kolmasosa perhehoidossa. Kummassakin ikäryhmässä oli tämän hoitomuodon osuus suurempi kokopäivätyössä käyvien kuin kaikkien ansiotyössäkäyvien äitien lapsilla.

Laitospäivähoidossa oli kaikkiaan $20 \%$ ansioäitien 3-7vuotiaista lapsista. Alle kolmevuotiailla lapsilla ei haastattelutietojen perusteella tätä hoitomuotoa esiintynyt lainkaan.

Mu ussa hoidoss a olevien osuus oli suhteellisen pieni kummassakin e.m. ikäryhmässä. 


\section{Perhepäivähoito}

Erittäin hyviä tai hyviä olivat kokemukset äitien mielestä hieman yli puolessa eli $53 \%$ :ssa tapauksista, melko hyviä $30 \%$ :ssa ja huonoja 15 $\%$ :ssa tapauksista. Lasten iän mukaan olivat kokemukset perhepäivähoidosta äitien mielestä jostain syystä paremmat alle 3-vuotiaiden kuin 3-7-vuotiaiden lasten kannalta. Kokonaisuudessaan olivat kokemukset tästä hoitomuodosta siis melko myönteisiä.

Pyydettäessä äitejä kertomaan missä suhteessa edellämainitut kokemukset olivat hyviä tai huonoja saatiin myönteisiä perusteluja luonnollisesti enemmän kuin kielteisiä. Toisaalta on todettava, että kielteisiä kokemuksia saaneista esitti perusteluja suhteellisesti suurempi osa (71 \%) kuin myönteisiä kokemuksia saaneista (55\%).

Myönteisiä kokemuksiaan perustelleista kiinnitti lähes puolet huomiota siihen, että lapsi oli viihtynyt hyvin hoitopaikassaan tai että hänellä oli ollut seuraa muista. Toiseksi suurimman ryhmän, neljänneksen $(27 \%)$, muodostivat äidit, joiden esittämät perustelut koskivat tyytyväisyyttä lapsen fyysiseen hoitoon: lapsi sai heidän mielestään riittävästi ravintoa ja lepoa tai hoito oli säännöllistä tai puhtaus hyvä. Lasten hoitoon lähinnä henkisistä syistä tyytyväisiä oli viidennes (21 \%). Heidän kokemuksissaan olivat myönteisinä puolina sellaiset seikat kuin: hoidon yksilöllisyys, hoitajan hyvä suhtautuminen lapsiin ja huomion kiinnittäminen myös kasvatus- ja opetuspuoleen. Muina perusteluina esitettiin lisäksi matkojen lyhyys ja joustavuus sairaustapauksissa.

Kielteisiä kokemuksia perustelleista viittasi $40 \%$ siihen, että lapsen sopeutuminen oli äidin mielestä syystä tai toisesta epätyydyttävää. Tällaisia syitä olivat $\mathrm{mm}$. seuraavat: lapsi vierastaa, pelkää tai hänen on vaikea tottua aina uusiin olosuhteisiin ja edelleen, että lapsi saa huonoja vaikutteita, hoitaja on hermostunut tai että kasvatusperiaatteet menevät ristiin vanhempien asenteiden kanssa. Hoidon puutteellisuuteen nojautui $35 \%$ k.o. perusteluista. Aiheina oli ruokailun tai ulkoiluttamisen epäsäännöllisyys, se että ulkoilua ei valvottu tai ettei lasta puettu asianmukaisesti ulosvietäessä. Eräs äideistä viittasi myös siihen, että hoito "jäi vähän niin ja näin", koska hoitoperheessä oli liian paljon omia lapsia. Muita kielteisille kokemuksille esitettyjä perusteluja, joiden osuus oli kaikkiaan $25 \%$ kaikista kysymyksessä olevista perusteluista, olivat: lapsen alttius tartuntataudeille sekä matkojen pituus ja kuljetuksen hankaluus etenkin aamuisin.

Kokemuksia perhepäivähoidosta tiedusteltiin myös vanhempien kannalta. Perusteluja niiden myönteisyydestä tai kielteisyydestä esitettiin tosin hyvin vähän. Mainittakoon kuitenkin, että myönteisiä kokemuksia perusteltiin pääasiassa hoidon luotettavuudella, minkä vuoksi äiti voi lähteä rauhassa työhön ja kielteisiä hoidon kalleudella ja sillä, että lasta pidettiin vain rahan vuoksi tai että kuljetus oli matkojen vuoksi hankalaa. 
Perhepäivähoidon ehkä pahimpana haittapuolena on yleensä pidetty hoitopaikkojen suurta vaihtuvuutta. Uuden hoitopaikan hankkiminen aiheuttaa paitsi äidille huolta ja vaivaa myös usein lapselle ainakin aluksi sopeutumisvaikeuksia. Mitä nuorempi tai herkempi lapsi on, sitä enemmän hänelle tuottaa pelkoa ja turvattomuuden tunteita hoitajan vaihtuminen ja sitä tärkeämpää luonnollisesti olisi, että hänellä olisi vakinainen hoitaja, johon hän voi luottaa. Hoitopaikkojen vaihtuvuuden selvillesaamiseksi kysyttiin äideiltä, kuinka monessa eri hoitopaikassa heidän eri ikäiset lapsensa olivat olleet hoidettavina.

Keskimäärin olivat alle 3 -vuotiaat lapset olleet hoidettavina 1.6 perheessä ja 3-7-vuotiaat 2.1 perheessä. Kolmessa tai useammassa hoitopaikassa olleiden osuus taas oli ensiksi mainituilla $12 \%$ ja viimemainituilla n. kolmasosa. Varsin hämmästyttävältä vaikuttaa se, että alle kolmevuotias lapsi on kahdessa tapauksessa joutunut olemaan viidessä tai kuudessa eri hoitopaikassa. Kokonaisuutena ottaen voitaneen vaihtuvuutta kuitenkin pitää melko kohtuullisena, ottaen huomioon, että n. $60 \%$ alle 3-vuotiaista oli ollut vain yhdessä hoitopaikassa ja että lisäksi hoitopaikkaa kerran vaihtaneita oli noin neljännes kun taas vanhemmista lapsista oli n. kaksi kolmasosaa ollut yhdessä tai kahdessa hoitopaikassa.

Hoitoperheen tai hoitoa tarvitsevan lapsen perheen muuttamisen tai hoitajan ansiotyöhön menemisen johdosta tapahtuneita muutoksia ei voitane pitää niin haitallisina kuin hoitopaikasta saatujen negatiivisten kokemusten vuoksi tapahtuneita vaihtumisia. Syyt hoitopaikkojen muutoksiin jakaantuivat seuraavasti:

Muuttaminen, hoitajan ansiotyöhön meno tms.

$\begin{array}{r}85 \\ 4 \\ 40 \\ \hline 129\end{array}$

Noin kaksi kolmasosaa hoitopaikkojen muutoksista tapahtui siis luonnolliselta tuntuvista syistä (muuttaminen jne.) ja noin yksi kolmasosa joko siksi, ettei lapsi viihtynyt hoitopaikassaan, koska hänellä oli erilaisia sopeutumisvaikeuksia tai ettei hoitoperhe hoidollisesti täyttänyt sille asetettuja vaatimuksia.

\section{Laitospäivähoito}

\section{Kokopäivähoito}

Vaikka olosuhteet laitospäivähoidossa ovat jatkuvasti parantuneet ja pyrkimyksenä on nykyisin luoda kaikin tavoin, myös psykologiselta ilmapiiriltään kotia muistuttava ympäristö, ei kuitenkaan voida olla varmoja, etteikö koko päivän kestävä laitoshoito olisi rasittavaa lapsille ja etteikö 
sillä olisi haitallisia vaikutuksia heidän kehitykselleen. Hoitajien äkilliset vaihtumiset ja henkilökunnan vähäisyydestä johtuvat puutteellisuudet ovat ehkä pahimpia hyvinkin järjestettyyn laitospäivähoitoon liittyviä riskejä. Mikäli laitosmainen kokopäivähoito kestää pitemmän ajan, esim. useita vuosia, voidaan sen aiheuttamien haittavaikutusten olettaa korostuvan. Kokopäivähoidon mahdollista vaikutusta lapsiin esim. perhepäivähoitoon verrattuna on kuitenkin vaikea saada selville. Tämä johtuu siitä, että k.o. valintaperusteiden mukaan - ainakin kunnallisilla - kokopäiväosastoilla olevat lapset ovat yleensä vaikeimmassa sosiaalisessa asemassa olevien perheiden lapsia, jolloin pelkän hoitomuodon vaikutusta on vaikea "irrottaa" heidän kehitykseensä todennäköisesti vaikuttavista muista haittatekijöistä. Myös vertailuryhmän muodostaminen vastaavanlaisista olosuhteista tulevista ja kokopäivän jossain muussa hoidossa (esim. perhepäivähoidossa) olevista lapsista on ilmeisen vaikeata. Pitkäaikaisen kokopäivähoidon vaikutuksia on kuitenkin yritetty tutkia $\mathrm{mm}$. vertaamalla lastentarhojen kokopäiväosastolla määrätyn ajan olleita ja saman lastentarhan puolipäiväosastolla olevia lapsia tietyissä suhteissa keskenään. Tällöin voitiin todeta, että kokopäivälapsien käyttäytymisessä lastentarhoissa ilmeni enemmän jännittyneisyyttä sekä neuroottisia oireita kuin osan päivästä kotihoidossa olevien lasten käyttäytymisessä, ja että »lasten sosiaalinen kehitys edistyy yleensä paremmin oman äidin hoidossa kuin päivähoidossa, johon liittyy ainakin kahden vuoden laitosmainen päivähoito» (Räsänen 1966). Avoimeksi jää kuitenkin esim. perhepäivähoidon vaikutus, jonka arvioimiseen ei edellä mainittuja tuloksia voida käyttää.

Tämän tutkimuksen yhteydessä voidaan asiaa tarkastella vain lasten vanhempien saamien kokemusten valossa. On kuitenkin mahdollista, etteivät äidit ole osanneet arvioida laitoshoidon etuja ja haittoja ja että kokemusten positiivisuutta on liioiteltu. Tiedusteltaessa kokemuksia tästä hoitomuodosta lasten kannalta ja perheen kannalta olivat kokemukset hyvät lasten kannalta $82 \%$ :ssa ja vanhempien kannalta $90 \%$ :ssa tapauksista, joita oli kaikkiaan kolmekymmentäkolme. Koska edellä mainittujen suhdelukujen erotus on melko suuri ja koska kokemukset osoittautuivat paremmiksi perheen kannalta kuin lasten kannalta, lienee kokemuksia arvioitaessa otettu huomioon ennen kaikkea hoitomuodon taloudellisuus. Verrattuna esim. perhepäivähoitoon, josta kokemukset olivat likipitäen yhtä hyviä perheen kuin lastenkin kannalta, olivat kokopäiväosastoista saadut kokemukset, siis äitien mielestä, selvästi myönteisemmät. Kokopäiväosastoista saatuja myönteisiä kokemuksia perusteltiin hieman yli puolessa tapauksista sillä, että lastentarhassaolo on lapsille kehittävää; he oppivat lauluja ja leikkejä ja suhtautumista muihin sekä itsenäistyvät ja heillä on seuraa muista. Noin toinen puoli perusteluja esittäneistä taas viittasi lastentarhassa saadun hoidon säännöllisyyteen ja luotettavuuteen. Kielteisiä kokemuksia esitti vain kaksi äitiä, toinen heistä perusteli kokemuksiaan kysymyksessä olevan hoitomuodon 
joustamattomuudella ja toinen matkojen hankaluudella. Vanhempien kannalta perustuivat myönteiset kokemukset yleisimmin siihen, että hoitomuoto oli taloudellinen ja eräässä tapauksessa viitattiin myös perheen parempaan eheyteen, koska anoppi ei enää "sotkeutunut" perheen asioihin. Kielteisiä kokemuksia perheiden kannalta ei esiintynyt lainkaan.

\section{Puolipäivähoito}

Lastentarhojen puolipäiväosastoja, joissa lapset ovat noin neljä tuntia päivässä, pidetään yleensä varsinkin leikki-ikäisille suositeltavina ja kehittävinä. Ajan puolesta voidaan niiden katsoa olevan sopivia varsinkin silloin, kun äiti ei käy ansiotyössä lainkaan, tekee ansiotyötä kotona tai on osapäivätyössä sinä aikana kun lapsi on lastentarhassa. Kodin ulkopuolella kokopäivätyössä käyvien äitien lapsille hoitomuoto ei ehkä aina ole niin sopiva, mikäli lapset joutuvat olemaan yksin lopun ajan päivästä. Tutkimusperheiden lapsista olikin puolipäiväosastoilla vähemmän kokopäivätyössä käyvien kuin kaikkien ansiotyössäkäyvien äitien lapsia. Ensiksi mainituista oli $77 \%$ lopun ajan päivästä yksin tai vanhempien sisarusten hoidossa ja $22 \%$ naapurissa. Tilanne ei ilmeisesti ollut läheskään kaikissa tapauksissa tyydyttävä, sillä lähes puolet kysymyksessä olevista äideistä halusi saada lapsensa kokopäiväosastolle. Viimemainittu seikka kuvastuu myös vastauksissa siten, että muutamissa tapauksissa äidit ovat luokitelleet kokemukset puolipäiväosastoista vain "melko hyviksi» ja eräässä tapauksessa perheen kannalta "melko huonoiksi». Myönteisiä kokemuksia, jotka siis olivat erittäin vallitsevina, perusteltiin samalla tavoin kuin kokopäiväosastojenkin kohdalla.

\section{Lastenhoitokustannukset}

Lastenhoitokustannukset ansioäitiperheissä olivat keskimäärin 68 markkaa kuukaudessa. Ilman varsinaisia kustannuksia olivat lastenhoidon saaneet järjestettyä $35 \%$ kaikista ansiotyössäkäyvistä ja $24 \%$ kokopäivätyössä käyvistä äideistä. Hoitomuodoittain vaihtelivat kokopäivähoitokustannukset lasta kohti keskimäärin kuukaudessa siten, että ne olivat:

perhepäivähoidossa

lastenhoitajan tai kotiapulaisen hoidossa sukulaisen hoidossa kotona tai muualla laitospäivähoidossa

$\begin{array}{rcc}120 & \mathrm{mk} / \mathrm{kk} & (\mathrm{n}=80) \\ 82 & \Rightarrow & (\mathrm{n}=13) \\ 59 & \Rightarrow & (\mathrm{n}=51) \\ 44 & \Rightarrow & (\mathrm{n}=13)\end{array}$

Kallein kokopäivähoitomuoto perheen kannalta oli siis perhepäivähoito, josta äidit maksoivat keskimäärin 120 markkaa kuukaudessa lasta kohti kustannusten vaihdellessa 50 markasta 160 markkaan. Runsas toi- 
nen puoli kuului ryhmään, joka maksoi 100-129 markkaa kuukaudessa. Viimemainittua halvemmalla $(50-99 \mathrm{mk})$ oli saanut hoidon järjestymään $29 \%$ ja 130 markkaa tai yli joutui maksamaan $15 \%$ kysymyksessä olevista äideistä.

Toiseksi kalleimpana hoitomuotona oli lastenhoitajan tai kotiapulaisen avulla järjestetty hoito, joka tutkimusperheissä tuli maksamaan keskimäärin 82 markkaa lasta kohti ja siis halvemmaksi kuin perhepäivähoito lasta kohti. Huomattakoon kuitenkin, että viimemainituissa perheissä oli kaikissa vähintään kolme alle kouluikäistä lasta ja että kustannukset lasta kohti on laskettu siten, että ne perustuvat vain kotiapulaiselle maksettavaan rahapalkkaan. Todelliset kustannukset muodostuvat suuremmiksi kotiapulaisille kuuluvien luontoisetujen, kuten ruuan, asunnon ym. johdosta, mutta näiden etujen rahallista arvoa on kuitenkin vaikea arvioida. Viimemainittu seikka koskee myös hoitomuotoa sukulaisen hoidossa kotona, sillä tällöinkin oli isoäideille maksettava rahapalkka usein melko pieni ja noin kolmasosassa tapauksista sitä ei maksettu lainkaan, vaikka isoäidit toisaalta saivat palkkioksi hoidosta esim. asunnon, ruuan, vaatteita tms. Halvimmat olivat kokopäivähoitokustannukset laitoshoidossa, josta äidit maksoivat keskimäärin 44 markkaa kuukaudessa lasta kohden. ${ }^{1}$

\section{Aitien tyytyväisyys lasten hoitoon}

Äideille esitetyssä kysymyksessä: „Oletteko saaneet lastenhoidon järjestymään tyydyttävästi» oli vastausvaihtoehtojen asettelu, »kyllä tai ei» sellainen, että ei-vastauksia antaneilla voitaneen olettaa olevan melko vakavia epäkohtia lastenhoidon järjestelyissä tai toisaalta saattaa olla kysymys joko osaksi tai kokonaankin kustannuksista. Käsitteen sisällön täsmällinen määritteleminen on siis vaikeaa. Seuraavassa on asiaa yritetty selvittää siten, että »tyytyväisyyttä» verrataan hoitomuodoittain eri ikäryhmissä muistaen toisaalta, millaisia kokemuksia äideillä on edellä esitetyn perusteella ollut eri hoitomuodoista ja toisaalta millaiset ovat olleet niiden kustannukset.

Epätyydyttävin hoitomuoto alle 3-vuotiailla oli (mukana kokopäivätyössä käyvät) äitien mielestä "perheenjäsenen hoidossa kotona», johon oltiin tyytyväisiä vain hieman yli puolessa tapauksista. Tämä hoitomuoto, jonka suhteellinen osuus oli vähäinen (5\%), on ilmeisesti ollut epätyydyttävä näin nuorille lapsille »hoitajien» vuoksi, vaikkei se yleensä aiheutakaan kustannuksia. Muissa hoitomuodoissa oli tyytyväisyysprosentti melko korkea (yli $80 \%$ ). Mielenkiintoista on havaita, että 3-7-vuotiaille ei perhepäivähoitopaikkojen lukumäärällä ilmeisesti katsottu olevan yhtä

1 Laitoshoidossa peritään korvaus vain ruoasta, mutta ei hoidosta. 
suurta merkitystä kuin alle 3-vuotiaille, sillä tyytymättömyys kyseiseen hoitomuotoon riippuu heidän kohdallaan ilmeisesti enemmän kustannuksista ja muista tekijöistä. Alle kolmevuotiaiden hoitoon tyytyväisiä oli suhteellisesti eniten niissä, joiden lapset olivat sukulaisen hoidossa kotona tai muualla, mikä edelläesitettyjen äitien saamien kokemusten perusteella tuntuukin varsin luonnolliselta.

Vanhempien, 3-7 -vuotiaiden, lasten osalta eivät puolipäiväosastoilla olevien lasten äideistä läheskään kaikki (niistä, jotka kävivät kokopäivätyössä) olleet tyytyväisiä lastenhoitojärjestelyyn lähinnä siksi, ettei lasten hoitoa saatu koko päiväksi heidän mielestään järjestymään. Puolipäiväosastolle lapsensa saaneet, joista oli tyytyväisiä vain $54 \%$, ajattelevat ilmeisesti, että lasten ehkä sittenkin olisi turvallisempi olla kokopäiväosastolla, koska kerran äitikin on kokopäivätyössä; tyytymättömyys ei siis kohdistunut puolipäiväosastoihin sinänsä. Tyytyväisyys kokopäiväosastoihin nähden oli sataprosenttinen.

Perhepäivähoitoon tyytyväisten osuus 3-7-vuotiaiden lasten äideistä oli selvästi pienempi (69 \%) kuin alle kolmevuotiaiden. Perheenjäsenen hoidossa kotona olemista pidettiin puolestaan paremmin soveltuvana 3-7-vuotiaille kuin sitä nuoremmille lapsille. Kaikkiaan oltiin alle kolmevuotiaiden lasten hoitoon tyytyväisiä $85 \%$ :ssa ja 3-7-vuotiaiden hoitoon $77 \%$ :ssa tapauksista. Aiti ja lapsi-perheissä oli viimemainittujen lukujen suuruusjärjestys päinvastainen ja hoitoon tyytyväisten osuudet olivat $75 \%$ ja $88 \%$.

\section{Äidin työssäkäynnin vaikutus lapsiin}

Äidin työssäkäynnin vaikutuksen lapsiin voidaan olettaa riippuvan monista eri osatekijöistä. Tärkeimpänä voitaneen yleensä pitää sen ajan riittävyyttä, jonka äiti työssäkäynnistä huolimatta voi omistaa lapsille sekä lasten ja päivähoitajan välistä suhdetta. Myös äidin asennoitumisella työssäkäyntiin on todettu olevan merkitystä äidin ja lapsen väliselle suhteelle siten, että mikäli äidin asennoituminen työssäkäyntiin on myönteinen, ei haittavaikutuksia yleensä esiinny siinä määrin kuin päinvastaisessa tapauksessa (Nye-Hoffman 1963, 102). Samoin oletetaan luonnollisesti myös sen seikan, onko äiti ollut lastenhoitojärjestelyihin tyytyväinen vai ei, olevan yhteydessä äidin käsitykseen työssäkäynnin vaikutuksesta lapseen.

Asiaa tutkimusperheiltä tiedusteltaessa jaettiin kysymys kahteen osaan, toisaalta työssäkäynnin vaikutukseen fyysisen kunnon ja terveyden kannalta ja toisaalta henkisen kehityksen kannalta (taulukko 3).

Yleisvaikutelmana voidaan vastauksista todeta, ettei äidin työssäkäynnillä katsottu olevan kovinkaan monissa tapauksissa merkitystä lasten fyysisen kunnon ja terveyden kannalta, mutta hieman yleisimmin uskot- 
T a u lukko 3. Äidin työssäkäynnin vaikutus fyysiseen ja henkiseen kehitykseen

Table 3. Influence of the mother's employment on the physical and mental development of the child

\begin{tabular}{|c|c|c|}
\hline & $\begin{array}{c}\text { Fyysisen kunnon ja } \\
\text { terveyden kannalta } \\
\text { Physical condition } \\
\text { and development } \\
\% \\
\end{array}$ & $\begin{array}{c}\text { Henkisen kehityksen } \\
\text { kannalta } \\
\text { Mental condition } \\
\text { and development } \\
\%\end{array}$ \\
\hline \multirow{5}{*}{$\begin{array}{l}\text { Myönteinen } \\
\text { Favorable } \\
\text { Ei vaikutusta } \\
\text { No influence } \\
\text { Kielteinen } \\
\text { Unfavorable } \\
\text { Ei osaa sanoa } \\
\text { Cannot say }\end{array}$} & 3 & 6 \\
\hline & 79 & 69 \\
\hline & 10 & 16 \\
\hline & 8 & 9 \\
\hline & 100 & 100 \\
\hline
\end{tabular}

tiin sen vaikuttavan lasten henkiseen kehitykseen joko kielteisesti tai myönteisesti. Lasten fyysiseen kuntoon vaikuttavien tekijöiden, kuten ravinnon, ulkoilun ja levon suhteen on lasten hoito äidin mielestä siis ylläesitetyn perusteella ollut useimmissa tapauksissa tyydyttävä. Ne, jotka katsoivat työssäkäynnin olevan haitallista lapsille edellämainituissa suhteissa, perustelevat asiaa sillä, että lasten ravinto oli puutteellinen, lapset ovat väsyneempiä ja sillä että lapsilla on tartunnan vaara ja he ovat useammin sairaana. Haittavaikutuksia henkisen kehityksen kannalta, joita ansiotyössäkäyvät äidit uskoivat siis olevan $16 \%$ :ssa tapauksista, perusteltiin sillä, että lapset ovat hermostuneita ja rauhattomia ja että kasvatus kärsii. Noin puolet työssäkäynnin vaikutuksia kielteisinä pitävistä äideistä ei sen sijaan perustellut tarkemmin kantaansa. Lasten henkisen kehityksen kannalta työssäkäynnin vaikutusta myönteisenä pitävät viittasivat siihen, että toisten lasten seura hoitopaikoissa on kehittävää, että lapset itsenäistyvät paremmin tai että lapsille on hyväksi, kun äiti käy työssä (osapäivätyössä), koska hän on silloin itse virkeämpi.

Tutkittaessa aikaisemmin mainittujen osatekijöiden merkitystä sille, miten äiti katsoi työssäkäynnin vaikuttavan lasten henkiseen kehitykseen, saatiin tulokseksi, että kysymyksessä olevaan seikkaan vaikutti eniten se, oliko äiti saanut lasten hoidon järjestymään tyydyttävästi vai ei (taulukko 4). Tämä riippuu puolestaan melko huomattavasti varsinkin alle 3-vuotiaiden lasten osalta perhepäivähoitopaikkojen lukumäärästä.

Taulukosta 4 voidaan todeta, että niistä, jotka pitivät työssäkäynnin vaikutusta lasten kannalta myönteisenä, olivat kaikki saaneet lastenhoidon mielestään järjestymään tyydyttävästi, vastaavien prosenttilukujen ollessa niillä, jotka katsoivat, ettei työssäkäynnillä ollut vaikutusta, $83 \%$ ja niillä, jotka pitivät vaikutusta kielteisenä $67 \%$. Aitien käsitysten jakaan- 
Taulukko 4. Äidin ansiotyössäkäynnin vaikutus lapsen henkiseen kehitykseen ja äidin tyytyväisyys hoitoon

Table 4. Influence of mother's employment on the mental development of the child and mother's satisfaction with the day care arrangement

\begin{tabular}{|c|c|c|c|}
\hline $\begin{array}{l}\text { Aidin ansiotyössä- } \\
\text { käynnin vaikutus } \\
\text { Influence of } \\
\text { mother's employment }\end{array}$ & $\begin{array}{c}\text { Tyytyväinen } \\
\text { hoitoon } \\
\text { Satisfied } \\
\%\end{array}$ & $\begin{array}{c}\text { Tyytymätön } \\
\text { hoitoon } \\
\text { Dissatisfied } \\
\%\end{array}$ & $\begin{array}{c}\text { Yhteensä } \\
\text { Total } \\
\%\end{array}$ \\
\hline $\begin{array}{l}\text { Myönteinen } \ldots \\
\text { Favorable }\end{array}$ & 100 & - & 100 \\
\hline $\begin{array}{l}\text { Ei vaikutusta } \\
\text { No influence }\end{array}$ & 83 & 17 & 100 \\
\hline $\begin{array}{l}\text { Kielteinen } \\
\text { Unfavorable }\end{array}$ & 67 & 33 & 100 \\
\hline $\begin{array}{l}\text { Ei osaa sanoa } \\
\text { Cannot say }\end{array}$ & 81 & 19 & 100 \\
\hline $\begin{array}{l}\text { Yhteensä ........ } \\
\text { Total }\end{array}$ & 81 & 19 & 100 \\
\hline
\end{tabular}

Ta ulukko 5. Aidin työssäkäynnin vaikutus lapsen henkiseen kehitykseen ja lapsen suhtautuminen hoitajaan

Table 5. Influence of mother's employment on mental development of the child and child's relationship to person taking care of him

\begin{tabular}{|c|c|c|c|c|c|}
\hline \multirow{3}{*}{$\begin{array}{l}\text { Äidin työssäkäynnin } \\
\text { vaikutus } \\
\text { Influence of mother's } \\
\text { employment }\end{array}$} & \multicolumn{5}{|c|}{$\begin{array}{l}\text { Lapsen suhtautuminen hoitajaan } \\
\text { Child's relationship to person taking care of him }\end{array}$} \\
\hline & $\begin{array}{l}\text { Erittäin } \\
\text { hyvä }\end{array}$ & Hyvä & $\begin{array}{l}\text { Kohta- } \\
\text { lainen }\end{array}$ & Huono & Yhteensä \\
\hline & $\begin{array}{c}\text { Very } \\
\text { good } \\
\%\end{array}$ & $\begin{array}{c}\text { Good } \\
\%\end{array}$ & $\begin{array}{c}\text { Fair } \\
\%\end{array}$ & $\begin{array}{r}B a d \\
\%\end{array}$ & $\begin{array}{r}\text { Total } \\
\%\end{array}$ \\
\hline $\begin{array}{l}\text { Myönteinen } \\
\text { Favorable }\end{array}$ & 24 & 70 & - & 6 & 100 \\
\hline $\begin{array}{l}\text { Ei vaikutusta } \\
\text { No influence }\end{array}$ & 9 & 80 & 8 & 3 & 100 \\
\hline $\begin{array}{l}\text { Kielteinen } \\
\text { Unfavorable }\end{array}$ & 16 & 54 & 24 & 6 & 100 \\
\hline $\begin{array}{l}\text { Ei osaa sanoa } . . . . \\
\text { Cannot say }\end{array}$ & 9 & 69 & 9 & 13 & 100 \\
\hline Yhteensä - Total & 12 & 73 & 10 & 5 & 100 \\
\hline
\end{tabular}

tumisen työssäkäynnin vaikutuksen mukaan voitiin todeta eroavan toisistaan myös siinä suhteessa, millaisena äidit pitivät lasten suhtautumista päivähoitajaan. Taulukosta 5 nähdään, että niistä äideistä, joiden mielestä työssäkäynnin vaikutus oli myönteinen, katsoi myös valtaosa lapsensa suhtautumisen hoitajaan olevan hyvän.

Åidin asennoitumista työssäkäyntiin mitattiin kysymyksellä, tuntuuko työssäkäynti äidin mielestä lähinnä miellyttävältä vai epämiellyttävältä. 
Noin $76 \%$ äideistä vastasi, että työssäkäynti tuntui heistä joko hyvin miellyttävältä $(13 \%)$ tai miellyttävältä $(62 \%), 19$ prosentin ollessa epävarmoja ja vain $6 \%$ mielestä tuntui työssäkäynti ikävältä.

Tarkasteltaessa eroavatko äidit suhtautumisessaan työhön siitä riippuen, miten he katsovat työssäkäynnin vaikuttavan lapsiin, voitiin todeta, että vaikutusta myönteisenä pitäneistä suhtautui myös suhteellisesti suurin osa (31 \%) työssäkäyntiin varsin positiivisesti, eikä heistä yhdestäkään tuntunut työssäkäynti ikävältä. Toisaalta taas niistä, jotka pitivät vaikutusta kielteisenä, tuntui työssäkäynti miellyttävältä vain $6 \%$ :ssa ja ikävältä sen sijaan $8 \%$ :ssa tapauksista.

\section{Äidinpalkka}

Kuten jo tutkimusselostuksen alussa todettiin on tutkimuksessa eräänä ratkaisuvaihtoehtona tarkoitus selvittää kysymystä ns. äidinpalkan maksamisesta. Esiintulevia haastattelututkimuksen avulla selvitettävissä olevia ongelmia olivat tällöin ensiksi yleinen suhtautuminen äidinpalkkaan ja kysymys siitä, minkä ikäisten lasten äideille äidinpalkkaa haastateltavien mielestä tulisi maksaa. Toiseksi voidaan kysymystä selvittää tutkimusperheiden osalta omakohtaisesti niiden vastausten perusteella, joita äidit antoivat kysymyksiin, jäisivätkö he kotiin, jos saisivat äidinpalkkaa ja minkä suuruinen äidinpalkan tulisi olla, jotta perhe voisi tulla toimeen ilman vaimon ansiotuloja.

\section{Suhtautuminen äidinpalkkaan}

Koska kaikkien haastateltavien ei voitu olettaa tuntevan äidinpalkkakäsitteen sisältöä, muotoiltiin heidän suhtautumistaan koskeva kysymys siten, että siinä tavallaan määriteltiin äidinpalkka. Kysymykseen, pitäisikö yhteiskunnan äidinpalkkaa maksamalla suoda äideille taloudelliset mahdollisuudet olla kotona ja hoitaa itse lapsiaan niin kauan kun nämä ovat pieniä, vastasi myöntävästi suurin osa sekä tutkimusperheiden äideistä $(88 \%)$ että isistä $(90 \%)$. Tulosten suuri myönteisyys saattaa osaksi johtua kysymyksen asettelusta, eikä myöskään tutkimusperheiden taloudellisen ja sosiaalisen aseman voida olettaa olevan tässä suhteessa vailla merkitystä. Toisaalta verrattaessa viimeksi mainittuja lukuja äidinpalkkakysymyksestä irrallaan esitetystä, lähes vastaavan sisältöisestä väittämästä (naimisissa olevalla naisella tulee olla mahdollisuus olla kotona niinkauan kun lapset ovat alle kouluiän) saatuun vastausjakautumaan, olivat »ehdottomasti samaa mieltä» $(72 \%)$ ja sjokseenkin samaa mieltä» (15\%) olevien osuudet naisilla yhteensä lähes yhtä suuret (87\%) kuin äidinpalkkakysymykseen myönteisesti vastanneiden osuus. Samoin oli asia 
miesten osalta. Kotona olevista äideistä vastasi kysymyksessä olevaan väittämään myönteisesti $91 \%$ ja äidinpalkan maksamista kannatti $90 \%$, vastaavien lukujen ollessa ansiotyössäkäyvillä äideillä jonkun verran pienemmät $(85 \%)$.

Äidinpalkkaa kannattaviin, myönteisiin vastauksiin liitetyistä varauksista (joita tosin oli kaikkiaan aika vähän) oli yleisin se, että äidinpalkkaa tulisi myöntää vain, jos perhe ellä on us e a m p i a la psia. Eräässä tapauksessa oli äiti sitä mieltä, että äidinpalkan maksaminen on paikallaan vain sitä harkinnan mukaan tarvitseville. Myönteisiä vastauksia vahvistavina perusteluina esitettiin äitien taholta joissakin tapauksissa, että äidinpalkka olisi ehdottomasti paras ratkaisu. Epävarmalle kannalle asettuneista, joita oli yllättävän vähän (miehistä $5 \%$ ja äideistä $7,5 \%$ ), perusteli osa kantaansa sillä, että äidinpalkan maksaminen riippuu varallisuudesta. Pari äitiä oli lisäksi sitä mieltä, ettei ole varma, kuuluuko asia yhteiskunnalle, koska toiset joutuvat maksamaan sen veroina. Kielteisesti vastanneista, joiden suhteelliset osuudet olivat pienimmät, viittasivat perheenisät siihen, että lapset ovat jokaisen henkilökohtainen asia tai ettei pidä hankkia lapsia, jollei pysty niitä elättämään, äitien jättäessä vastauksensa kielteisissä tapauksissa perustelematta.

Tiedusteltaessa lasten vanhemmilta, minkä ikäisten lasten äideille äidinpalkkaa heidän mielestään olisi myönnettävä, saatiin taulukon 6 mukainen jakautuma.

Taulukosta voidaan todeta, että suurimman ryhmän (yli puolet) sekä isistä että äideistä muodostivat ne, jotka pitivät annetuista vaihtoehdoista parhaana lasten alaikärajana seitsemää vuotta. Kuuteentoista vuoteen asetti lasten alaikärajan $15 \%$ äideistä ja $22 \%$ isistä. Viimeksi mainittua ikärajaa perusteli osa äideistä sillä, että erityisesti teini-ikäiset lapset tarvitsevat psykologista tukea, minkä vuoksi äidin olisi hyvä olla kotona. Ilmeistä on kuitenkin, ettei ikäraja (ainakaan alle kouluikäisten lasten osalta) ole äidinpalkan tarkoituksenmukaisuuden kannalta yhtä tärkeä tekijä kuin alle kouluikäisten lasten lukumäärä. Saattaahan perheessä olla neljäkin alle kouluikäistä lasta (3-4-5- ja 6-vuotias), vaikka kaikki heistä ovatkin yli kolmevuotiaita, jolloin ehkä monissa tapauksissa olisi tarkoituksenmukaisempaa maksaa äidille äidinpalkkaa kuin sijoittaa lapset esim. lastentarhan kokopäiväosastolle.

\section{Äitien mahdollinen kotiinjäänti}

Äidin kotiinjäämiseen mahdollisesti vaikuttavia tekijöitä oletetaan olevan mm. alle kouluikäisten lasten lukumäärän, äidin siviilisäädyn, työsuhdekysymysten; lisäksi äidinpalkan oletetulla määrällä voitiin otaksua olevan merkitystä mahdollista kotiinjääntiä harkittaessa. 
Taulukko 6. Tutkimusperheiden mielipiteet lasten ikärajasta äidinpalkkaa myönnettäessä

Table 6. Parents' opinion on the age limit for mother's wages grants

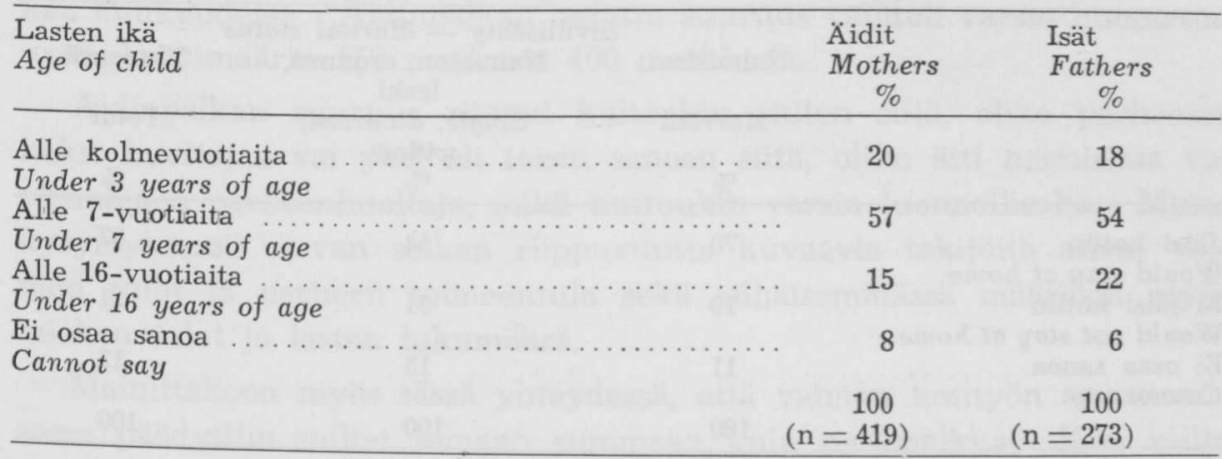

Taulukko 7. Äidin kotiinjääminen jos maksettaisiin äidinpalkkaa ja lasten lukumäärä

Table 7. Distribution of mothers' preference to remain at home if receiving mother's wages, according to number of children

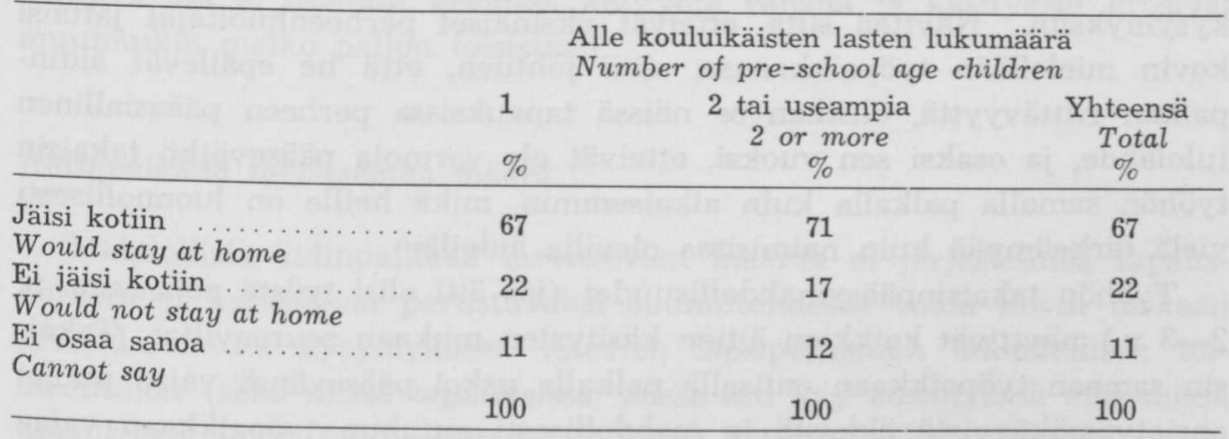

Alle kouluikäisten lasten 1 u kumäärän vaikutusta ei tutkimusaineiston perusteella voitu yleisemmin selvittää muuta kuin kahden ryhmän, yksilapsisten ja kaksi tai useampi lapsisten äitien osalta, sillä ansiotyössä käyviä äitejä, joilla oli kolme tai useampia alle kouluikäisiä lapsia, oli tutkimusperheissä vain 8 (taulukko 7).

Yksilapsisista ansiotyössäkäyvistä äideistä piti kotiinjääntiä mahdollisena (jos saisi äidinpalkkaa) kaksi kolmasosaa ja kaksi tai useampi lapsisista $71 \%$, joten ero näiden ryhmien välillä ei ollut kovinkaan suuri. Keskimäärin ilmoitti $67 \%$ ansioäideistä pitävänsä kotiinjääntiä mahdollisena, $22 \%$ vastatessa kieltävästi.

Siviilisäädyn voitiin todeta sen sijaan vaikuttavan mahdolliseen kotiinjääntiin enemmän kuin alle kouluikäisten lasten lukumää- 
Ta ulukko 8. Äidin kotiinjääminen, jos maksettaisiin äidinpalkkaa, siviilisäädyn mukaan

Table 8. Distribution of mothers' preference to remain at home if receiving mother's wages, according to marital status

\begin{tabular}{|c|c|c|c|}
\hline & $\begin{array}{c}\text { Naimisissa } \\
\text { Married } \\
\%\end{array}$ & $\begin{array}{c}\text { Siviilisääty - Marital status } \\
\text { Naimaton, eronnut, } \\
\text { leski } \\
\text { Single, divorced, } \\
\text { widow } \\
\%\end{array}$ & $\begin{array}{c}\text { Yhteensä } \\
\text { Total } \\
\%\end{array}$ \\
\hline \multirow{4}{*}{$\begin{array}{l}\text { Jäisi kotiin ........... } \\
\text { Would stay at home } \\
\text { Ei jäisi kotiin ......... } \\
\text { Would not stay at home } \\
\text { Ei osaa sanoa .......... } \\
\text { Cannot say }\end{array}$} & 70 & 54 & 67 \\
\hline & 19 & 31 & 21 \\
\hline & 11 & 15 & 12 \\
\hline & 100 & 100 & 100 \\
\hline
\end{tabular}

rän, sillä naimisissa olevista ansiotyössäkäyvistä äideistä jäisi ilmoituksensa mukaan kotiin $70 \%$ ja yksinäisistä perheenhuoltajista (naimattomat, eronneet ja lesket) vain $54 \%$ (taulukko 8).

Ero suhtautumisessa kotiinjäämiseen naimisissa olevien ja yksinäisten perheenhuoltajien välillä liittyy läheisesti taloudellisiin- ja työsuhdekysymyksiin. Näyttää siltä, etteivät yksinäiset perheenhuoltajat jättäisi kovin mielellään työpaikkaansa, siitä johtuen, että he epäilevät äidinpalkan riittävyyttä, olisihan se näissä tapauksissa perheen pääasiallinen tulolähde, ja osaksi sen vuoksi, etteivät ole varmoja pääsevätkö takaisin työhön samalla palkalla kuin aikaisemmin, mikä heille on luonnollisesti vielä tärkeämpää kuin naimisissa oleville äideille.

Työhön takaisinpääsymahdollisuudet (jos äiti olisi työstä pois esim. n. 2 -3 v.) näyttivät kaikkien äitien käsitysten mukaan seuraavilta: Takaisin samaan työpaikkaan entisellä palkalla uskoi pääsevänsä vajaa puolet ansiotyössäkäyvistä äideistä ja mahdollisesti muuhun työpaikkaan vajaa neljännes. Siitä, että kysymystä ei ilmeisesti oltu aikaisemmin harkittu tai siitä ei oltu jouduttu ottamaan selvää, oli osoituksena »ei-osaa-sanoa» tai "on-epävarma» -vastausten suhteellisesti varsin suuri osuus, $35 \%$. Ilmeistä on, että työnantajien suhtautumisella tulisi olemaan äidinpalkkajärjestelmän toteutumisen kannalta melko suuri merkitys, sitä suurempi mitä »laajemmalle» järjestelmä ulotettaisiin.

\section{Aidinpalkan suuruus}

Varsin mielenkiintoinen kysymys tutkimustehtävän kannalta on äidinpalkan halutun suuruuden selvittäminen. Asiaa tiedusteltiin ansiotyössäkäyviltä äideiltä kysymällä, kuinka paljon he arvelivat perheen tarvitsevan ns. äidinpalkkaa, jotta se tulisi toimeen ilman vaimon ansiotuloja. 
Äidinpalkan keskimääräiseksi suuruudeksi saatiin $314 \mathrm{mk}$ kuukaudessa, jolloin voitiin todeta, että se kytkeytyy melko läheisesti äidille kuukausittain jäävään netto-ansioon, jolla tarkoitetaan äidin nettopalkkaa työssäkäyntikustannukset vähennettynä ja joka oli keskimäärin 325 markkaa kuukaudessa. Äidinpalkan haluttu suuruus vaihteli varsin huomattavasti, keskimäärin 150 markasta 400 markkaan.

Aidinpalkan suuruus riippui kuitenkin eniten siitä, oliko perheessä kaksi huoltajaa vai yksi eli toisin sanoen siitä, oliko äiti naimisissa vai yksinäinen perheenhuoltaja, mikä tuntuukin varsin luonnolliselta. Muita kysymyksessä olevan seikan riippuvuutta kuvaavia tekijöitä olivat vaimon tulot ja perheen toimeentulo sekä vähäisemmässä määrässä myös miehen tulot ja lasten lukumäärä.

Mainittakoon myös tässä yhteydessä, että vaimon kotityön arvostamisessa päädyttiin miltei samaan summaan kuin nettopalkka. Kun niille perheille, joissa äiti ei käynyt ansiotyössä, esitettiin kysymys, »Minkä arvoiseksi arvostatte (vaimonne) työpanoksen(ne) taloudellisessa mielessä», kotityön taloudelliseksi arvoksi saatiin miesten vastausten perusteella keskimäärin $353 \mathrm{mk}$ ja naisten $336 \mathrm{mk}$ kuukaudessa. Naisista arvioi n. $60 \%$ kotityön alle $300 \mathrm{mk}: \mathrm{n}$ arvoiseksi ja miehistä vastaavasti noin puolet; vähintään $40 \mathrm{mk}: \mathrm{ksi}$ arvioi sen naisista $16 \%$ ja miehistä $25 \%$. Huomattava osa ei osannut arvioida kotityötä rahana ja käsitykset erosivat muutoinkin melko paljon toisistaan.

\section{Aidinpalkkaa tarvitsevien määrä}

Mahdollista äidinpalkkaa tarvitsevien määrää ei järjestelmää tapauskohtaiseen harkintaan perustuvaksi suunniteltaessa voida kovin tarkasti arvioida, mutta kysymykseen tulevien lapsiperheiden taloudellisen toimeentulon (sekä niissä tapauksissa, joissa äiti käy ansiotyössä että niissä tapauksissa, joissa äiti on kotona) ja äitien kotiinjääntihalukkuuden perusteella voidaan asiasta saada jonkinlainen yleiskuva. Kysymystä pitemmällä tähtäyksellä ajateltaessa on kuitenkin otettava huomioon, että työllisyystilanne ym. saattavat huomattavastikin vaikuttaa äitien työhönosallistuvuuteen.

Kaikkiaan ilmoitti yhdessäasuvista aviopareista $13 \%$, että perhe ei lainkaan tulisi toimeen ilman vaimon ansiotuloja, $48 \%$, että perheen olisi vaikea tulla toimeen ja $39 \%$, että perhe tulisi silti kohtalaisen hyvin toimeen. Yksinäisten perheenhuoltajien osalta olivat vastaavat luvut: $83 \%$, $13 \%$ ja $4 \%$.

Yhdessä asuvista aviopareista, joilla miehen tulot olivat alle $500 \mathrm{mk}$ kuukaudessa (brutto), ei käsityksensä mukaan $36 \%$ tulisi toimeen lainkaan, mikäli vaimo jäisi pois ansiotyöstä, $57 \%$ :n olisi vaikea tulla toimeen ja $7 \%$ tulisi silti kohtalaisen hyvin toimeen. Edelleen voidaan 
todeta, että ei lainkaan toimeen tulevien osuus pienenee aviomiehen tulojen kasvaessa. Korkeimmassa tuloluokassa $(900-990 \mathrm{mk} / \mathrm{kk})$ on "vaikeasti toimeentulevien" osuuskin pienentynyt 22 prosenttiin ja kohtalaisen hyvin toimeentulevia olisi yli kolmeneljäsosaa.

Aidinpalkkaa mahdollisesti tarvitsevien lukumäärästä voidaan arvioida seuraavaa: Yhdessäasuvia aviopareja, joilla on vähintään kaksi lasta ja joilla aviomiehen tulot syystä tai toisesta ovat niin alhaiset, ettei perhe käsityksensä mukaan tulisi lainkaan toimeen tai sen olisi vaikea tulla toimeen ilman vaimon ansiotuloja, on 382 ja äiti ja lapsi -perheitä vastaavasti n. 125 eli yhteensä noin 500 perhettä. Haastattelutulosten perusteella voidaan näiden perheiden äideistä noin $60 \%$ eli n. 300 äidin olettaa jäävän kotiin ansiotyöstä, mikäli se heille olisi taloudellisesti mahdollista. Viimeksi mainittuun lukuun on kuitenkin periaatteessa lisättävä niiden vähintään kaksilapsisten perheiden lukumäärä, joissa äiti ei ole tutkimusajankohtana käynyt ansiotyössä, mutta joissa perheen taloudellinen toimeentulo on huono. Tällaisia perheitä on n. 115 ja heidän osaltaan jää käytännössä selvitettäväksi, missä tapauksissa taloudellisen tuen tarpeessa oleva perhe olisi luettava äidinpalkkajärjestelmän piiriin ja missä tapauksissa perheelle olisi myönnettävä huoltoapua, jota se jo ehkä aikaisemminkin on saanut. Eräänä ratkaisuperiaatteena viimeksimainituissa tapauksissa lienee pidettävä äidin työkykyisyyttä.

\section{Aitien työssäkäyntitoivomukset}

Osapäivätyömahdollisuuksien lisääminen tarjoaisi myös erään ratkaisun, jonka avulla alle kouluikäisten lasten päivähoidon ja etenkin kokopäivähoidon tarvetta voitaisiin pienentää. Osapäivätyö tekisi äideille mahdolliseksi säilyttää yhteyden työelämään ja ehkä hankkia tarpeelliset lisäansiot perheelle. Osapäivätyössäkäyntiä selviteltäessä on kuitenkin yleensä tultu siihen tulokseen, että se on keskimääräistä korkeamman ammattipätevyyden ja etupäässä muista kuin taloudellisista syistä ansiotyössäkäyvien ratkaisu (vrt. esim. Lastensuojelun Keskusliiton tutkimus: Ansioäitien lasten päivähuolto, 1959).

Kyseenalaista siis olisi toisiko osapäivätyö sopivaa ratkaisumahdollisuutta kovinkaan monille tutkimusperheiden äideistä. Asian selvittämiseksi kysyttiin ansiotyössäkäyviltä äideiltä, kävisivätkö he mieluimmin, jos saisivat vapaasti valita, kokopäivätyössä vai osapäivätyössä. Äitien työssäkäyntitoivomusten mukaan (taulukko 9) kävisi heistä mieluimmin osapäivätyössä puolet ja kokopäivätyössä hieman vähemmän, $42 \%$. Näyttää siis siltä, että n. kaksiviidesosaa tutkimusperheiden kokopäivätyössäkäyvistä äideistä kävisi mieluimmin osapäivätyössä. ${ }^{1}$ Äidin tähän asti

1 Tutkimusperheiden ansiotyössäkäyvistä äideistä todellisuudessa kävi kokopäivätyössä $80 \%$, osapäivätyössä $11 \%$ ja tilapäis- tai satunnaistyössä $9 \%$. 
T a u luk k o 9. Äitien työssäkäyntitoivomukset

Table 9. Mother's attitude toward going to work

\begin{tabular}{|c|c|c|c|}
\hline $\begin{array}{l}\text { Aidin bruttotulot } / \mathrm{kk} \\
\text { Mother's gross } \\
\text { income/months }\end{array}$ & $\begin{array}{l}\text { Kävisi mieluimmin } \\
\text { kokopäivätyössä } \\
\text { Would prefer full- } \\
\text { time employment } \\
\%\end{array}$ & $\begin{array}{l}\text { Kävisi mieluimmin } \\
\text { osapäivätyössä } \\
\text { Would prefer part- } \\
\text { time employment } \\
\text { \% }\end{array}$ & $\begin{array}{l}\text { Ei osaa } \\
\text { sanoa } \\
\text { Cannot say } \\
\quad \%\end{array}$ \\
\hline $\begin{array}{l}\text { Alle } 400 \mathrm{mk} \\
\text { Under } 400 \mathrm{Fm} \text { ks. }\end{array}$ & 40 & 52 & 8 \\
\hline 400-699 mk, Fmks. & 39 & 54 & 7 \\
\hline $700-999$ & 61 & 32 & 7 \\
\hline Yhteensä - Total & 42 & 51 & 7 \\
\hline
\end{tabular}

ansaitsemien tulojen merkityksestä työssäkäyntitoivomusten kannalta voidaan tutkimusperheiden osalta lisäksi päätellä, että alemmissa tuloluokissa on osapäivätyötä haluavien määrä keskimääräistä suurempi ja ylemmissä keskimääräistä pienempi.

\section{Päivähoitopaikkojen tarve}

Kuten tutkimuksen kuluessa on voitu todeta on päivähoitopaikkojen tarve riippuvainen varsin monista tekijöistä. Suppean, sosiaalisin perustein tapahtuvan toiminnan puitteissakin voitanee päivähoitopaikkojen kysynnän siis olettaa vaihtelevan. Päivähoitopaikkojen tarvetta tämän tutkimuksen yhteydessä arvioitaessa lienee lähdettävä siitä, kuinka suuri osa sosiaalisen päivähoitotoiminnan puitteissa kysymykseen tulevista äideistä ei ole saanut lastenhoitoa järjestymään joko taloudellisesti tai muuten tyydyttävästi ilman yhteiskunnan toimenpiteitä. Huomattakoon kuitenkin, että jo pelkästään väestönlisäyksen johdosta vastaavat tutkimusajankohtana saadut luvut (mikäli muiden asiaan vaikuttavien tekijöiden oletetaan olevan ennallaan) v. 1970 enää noin kolmea neljättä osaa silloisesta tarpeesta. Jo aikaisemmin kävi ilmi, että noin $84 \%$ tutkimusperheiden ansiotyössäkäyvistä äideistä oli saanut päivähoidon käsityksensä mukaan järjestymään tyydyttävästi, jolloin tyytymättömien osuus oli $16 \%$. Kokopäivätyössä käyvistä äideistä oli päivähoitojärjestelyihin tyytyväisiä kaikkiin ansiotyössäkäyviin äiteihin verrattuna kuitenkin hieman vähemmän, n. $80 \%$. Edelleen jakaantui viimemainittu osuus lasten iän mukaan siten, että se oli hieman suurempi nuorempien (alle 3-vuotiaiden) kuin 3-7-vuotiaiden lasten osalta. Lisäksi mainittakoon, että vastaavat luvut olivat äiti ja lapsi -perheissä 75 (alle 3-vuotiaat) ja $88 \%$.

Alle kolmevuotiaiden lasten hoitojärjestelyyn tyytymättömistä kokopäivätyössä käyvistä äideistä haluaisi lapselle mieluiten paikan lastenseimestä $93 \%$ ja hoitajan kotiin $7 \%$. Mikäli äidnpalkka-järjestelmä 
otettaisiin käytäntöön, jäisi kysymyksessä olevista äideistä ilmoituksensa mukaan kotiin $55 \%$, jolloin seimihoitoa haluavia jäisi loput eli 31 tapausta.

Vanhempien, 3-7-vuotiaiden, lasten päivähoitoon tyytymättömistä järjestäisi $17 \%$ hoidon mieluiten siten, että ottaisi lastenhoitajan kotiin ja $83 \%$ haluaisi lapselle hoitopaikan lastentarhan kokopäiväosastolta. Todettakoon jälleen, että viimeksi mainituissa tapauksissa jäisi äiti ilmoituksensa mukaan kotiin, jos saisi äidinpalkkaa, n. $57 \%$ :ssa tapauksista, joten jäännös eli lastentarhojen kokopäiväosastopaikkojen lisätarve olisi tämän mukaan noin 55 paikkaa.

Todettakoon vielä, että kaikkiaan oli alle kouluikäisiä lapsia, joiden kokopäivähoitoa ei oltu saatu järjestymään tyydyttävästi 226, joista oli alle 3-vuotiaita 72 ja $3-7$-vuotiaita 154 .

Aidinpalkka-järjestelmän avulla pystyttäisiin edellä sanotun perusteella siis arviolta tyydyttämään noin hieman yli puolet sosiaalisen toiminnan piiriin kuuluvasta kokopäivähoidon tarpeesta. Muu osa tarpeesta voitaisiin tyydyttää joko laitospäivähoitopaikkojen tai perhepäivähoitotoiminnan avulla. Koska päivähoitopaikkojen tarve on, kuten jo aikaisemmin todettiin, useista siihen vaikuttavista tekijöistä johtuen varsin vaihteleva, olisi perhepäivähoitotoiminnan kehittäminen tärkeätä sikäli, että se tarjoaisi joustavan ja säänneltävissä olevan ratkaisumahdollisuuden.

\section{Kirjallisuus}

Elfvengren, E. Naimisissa olevien naisten työhönosallistuvuus. Väestöntutkimuksen Vuosikirja VIII. Helsinki 1964.

Lastensuojelun Keskusliitto (K. Raitasuo). Ansioäitien lasten päivähuolto. Helsinki 1959.

Lie, H.-Egge, B. Behovet for dagsinstitusjoner for barn. Socialt Arbeid, 10, 1965 ja $1,1956$.

Mannerheimin Lastensuojeluliitto. Päiväkoti ja perhepäiväkoti. Vertaileva psykologinen tutkimus. Stockholm 1953.

Nye, I.-Hoffman, L. W. The Employed Mother in America. 1963.

Paaermaa, L. Naiset työmarkkinoilla. Pro gradu. Helsingin yliopisto. Helsinki 1965.

Ristimäki, T. Äitien työvoimaan kuuluminen ja lasten hoito äidin työssäollessa. Väestöntutkimuksen Vuosikirja VII. Helsinki 1962.

Räsänen, L. Pitkäaikaisen päivähoidon mahdollisista vaikutuksista lasten sosiaalisiin suhteisiin. Psykologian pro gradu. Helsinki 1966.

Salomaa, S. Ansiotyö ja perheenemäntä. Helsinki 1956.

Sociala Meddelanden 1-2, 1965. Familjedaghem.

Statens offentliga utredningar 1951: 15. Daghem och förskolor. Stockholm 1952.

Sumu, I. ja Varjotie, P. Espoon suuriperheiset ja huoltoavun saajat. Pro gradu. Helsinki 1965. 
Summary:

\title{
The Need for Full-time Day Care in the Commune of Espoo
}

\author{
By VIRPI SEPPANEN
}

The day care situation of pre-school aged children in the community of Espoo was studied by means of a sample drawn on the basis of the 1965 census. The research focused on the social service aspects of the day care problem. Interviews were carried out in 452 households, i.e. with about one fifth of all lower income families with at least one pre-school age child currently residing in Espoo (Table 1).

The purpose of the study was to explicate the factors connected with the need for day care in general and institutional full-time day care in particular. Data were obtained on the number of children, employment of the mother and the factors associated with it, as well as on the length of her working day, reasons for going to work, current arrangements for the care of the child while the mother is at work, the mother's satisfaction with the current arrangement, and her preferences for the day care of the child. In addition, the reaction to a new partial solution to the day care problem, smother's wages,, was also explored, since the borough of Espoo has been planning to establish a system of mother's wages to be granted on the basis of individual consideration to mothers with pre-school age children remaining at home.

The scope of the project is reflected in the fact that about 35 per cent of all children in Espoo under the age of 7 came from lower income families.

The following results of the study may be briefly mentioned:

The three most common arrangements for the day care of children were home care, individual care outside the home, and institutional day care. In families where the mother was working outside the home 43 per cent of the children under 3 years of age were taken care of at the respondent's home, 53 per cent were cared for in the home of some relative or other person, and 4 per cent had some other arrangement. None of the children under 3 years of age were in institutional day care. Among children between the ages of 3 and 7,40 per cent were in home care, 32 per cent in individual care outside the home, 20 per cent in institutional day care, and 8 per cent in other care (Table 2).

In general the worst disadvantage of individual day care outside the home has been considered to be the frequent changes in the place of care. In the present sample children under 3 years of age have been on the average in 1.6 different individual care, and those between the ages of 3 and 7 in 2.1 different individual care outside the home. This extent of instability is not unreasonable in view of the fact that about 60 per cent of the children under 3 years of age have been in only one place of care. The main reason for changing the child from one place to another was that the person taking care of the child had either moved or had taken on employment outside the home.

The mother's experience with full-day institutional day care was good from the point of view of the child in 82 per cent and from the point of view of the parents in 90 per cent of the cases. The inexpensiveness of this type of care must have played a major role in this favorable evaluation.

In the opinion of the mothers, the least satisfactory arrangement for children under 3 years of age was where children were taken care of by some member of the family at home. Slightly more than one half of the mothers felt this to be a satisfactory arrangement. Satisfaction with other types of day care arrangements was rather high $(80.0 \%)$. Among mothers of children under 3 years of age, compara- 
tively the most satisfied were those whose children were taken care of by some relative either in the respondents own home or somewhere else. Almost all the mothers of children between the ages of 3 and 7 who were in half-day care were dissatisfied that no full-day arrangement could be made for the child.

The majority of the mothers in the sample felt that their employment outside the home had no unfavorable effect on the child's physical or mental development (Table 3). The most influential factor in the response to this question was the type of current day care arrangement for the child (Table 4). The relationship to the person taking care of the child was also important. The majority of the mothers who felt that their work outside the home had a favorable effect on the child considered the relationship between the child and the person taking care of him to be good (Table 5).

76 per cent of the mothers reported that they enjoyed going to work, 6 per cent found it unpleasant and 19 per cent were uncertain.

The general reaction to the proposed mother's wages was quite positive. About 90 per cent of the fathers and mothers in the sample felt such a support to be necessary, although there was some variation according to the economic and social position of the respondents. The distribution of the responses to the question of giving up work in favor of staying at home with the child was as follows: 67 per cent would remain at home, 22 per cent would prefer to work, and 11 per cent couldn't say (Table 7). Preference to remain at home depended most on the fact whether the mother is married or is the single supporter of the child. In case of the former 70 per cent, in case of the latter 54 per cent would prefer to stay at home (Table 8.).

About one half of the working mothers, if given a free choice, would prefer to work part-time and 40 per cent would prefer to work in full-time jobs (Table 9).

The average amount of mother's wages considered adequate by the respondents was $314 \mathrm{Fmks}$ per month. This corresponds rather closely to the actual average net earnings of the mothers in the sample, which was $325 \mathrm{Fmks}$ per month after deducting expenditures for going to work and paying for the child's day care. However, it must be noted that not all the expenditures involved in going to work could be taken into account, and the figures are only averages. 